\title{
Får jag inte bestämma något själv? En studie av kvarstående beslutanderätt hos dementa äldre
}

\author{
EVA RYRSTEDT
}

Denna studie behandlar vilken kvarstående beslutanderätt en äldre dement person med en kognitiv funktionsnedsättning har, när en ställföreträdare som kan handla utan den äldre dementas samtycke, är förordnad. Studien omfattar både rättshandlingar och andra beslut.

\section{Introduktion}

Självbestämmande och skyddsbehov framstår idag som motstående entiteter. Art. 12 i FN:s konvention om rättigheter för personer med funktionsnedsättning bör ges tolkningen att en individ alltid ska ha full egen rättslig handlingskapacitet (Ryrstedt, 2014 a och b, se vidare General comment 2014, under 4, 8, 11 och 13). Samtidigt finns det en allmän uppfattning

Eva Ryrstedt är professor i civilrätt vid juridiska fakulteten, Lunds universitet. Artikeln ingår i ett projekt inom forskningsmiljön Äldrerätt, vilken miljö är finansierad av Ragnar Söderbergs stiftelse och Marianne och Marcus Wallenbergs stiftelse, www.jur.lu/elderlaw.se om att individen inte bör tillåtas att fatta vissa beslut för att denne behöver skyddas (Mattsson/ Broström/ Johansson, 2014, s. 181). Oavsett om självbestämmande eller skyddsbehov får genomslag i varje enskilt fall, ska det vara en gemensam utgångspunkt att den dementa äldre personens behov, intressen och önskningar generellt sett alltid står i fokus. Detta följer av de olika konventioner Sverige är bundet av (Ryrstedt, 2014b).

Det övertagande av den rättsliga handlingsförmågan som idag sker främst när den enskilde har förvaltare, men även i fall där god man är förordnad och den enskildes tillstånd är sådant att den gode mannen inte behöver något samtycke för 
att rättshandla, kan emellertid leda till att ställföreträdarens intresse istället styr rättshandlingarna (Odlöw, 2005, s. 267).

\section{Syfte}

I denna artikel är mitt syfte att fastställa i vilken mån en kvarstående beslutanderätt föreligger för den enskilde när denne är påverkad av demens i en sådan omfattning att en förvaltare är förordnad för hela personens livssituation, eller har en god man som kan fatta beslut utan att tillfråga sin huvudman. Jag använder fortsättningsvis benämningen ställföreträdare som en gemensam term för både en sådan god man och en förvaltare. Här är alltså fråga om när den enskilde själv får bestämma, vilket sätter frågan om självbestämmande på sin spets. Artikeln handlar enbart om relationen mellan den enskilde - huvudmannen-och ställföreträdaren.

Eftersom frågan ställs utifrån en rättslig utgångspunkt, avser den i första hand den formella beslutanderätten; alltså utgående från den rättighet den enskilde har att självständigt fatta ett beslut. Ur rättslig synvinkel är detta en viktig fråga, eftersom den besvarar vem som är den legitime beslutsfattaren. Den materiella förståelsen av ett ställningstagande spelar emellertid i vissa fall en betydelsefull roll för att en formell beslutanderätt ska föreligga. Detsamma gäller för frågan om den formella beslutanderätten tillgodoser den enskildes intressen.

Ett annat syfte är att undersöka vilka konsekvenserna kan bli av att en rättshandling, som till exempel äktenskap, inte alls kan ingås och vad detta i förlängningen kan leda till. Vidare är också frågan vilka rättsliga möjligheter den dementa äldre personen har att förändra sin situation när denne är missnöjd med ställföreträdaren.

Härtill kommer en diskussion om hur kvarstående beslutanderätt som finns idag, relaterar till FN:s konvention om rättigheter för personer med funktionsnedsättning, utsatthetsteorin och teorin om rätten som normativa mönster $i$ ett normativt fält.

\section{Metod}

De rättsliga frågorna kommer i första hand att diskuteras utifrån gällande rätt. Grunden är alltså den rättsdogmatiska metoden. Denna metod innebär att olika rättskällor används för att finna den gällande regeln. De mest auktoritativa rättskällorna är lagtext, förarbeten och prejudikat. Även andra rättskällor kan dock vara av betydelse och här är doktrin ett betydelsefullt exempel (Lehrberg, 2010, s. 84ff.). Eftersom emellertid den fråga som är grundläggande för min studie - kvarstående beslutanderätt - med ett par mindre undantag inte alls berörs i lagtext och endast mycket kortfattat i förarbeten och doktrin, är det svårt att dra säkra slutsatser om gällande rätt. Jag måste därför använda en mindre auktoritativ rättskälla. Denna består av uttalanden från Socialstyrelsens etiska råd rörande kvarstående beslutanderätt för dementa äldre. Dessa uttalanden representerar "ett sätt att tänka" (se härför Etik i socialtjänsten $\mathrm{u}$ å). Sådana publikationer från myndigheter har lågt värde som rättskälla.

Jag har även genomfört intervjuer, vilket inte kan ses som en rättskälla i 
vanlig mening. Jag har då använt mig av en kvalitativ metod, i form av semistrukturerade informantintervjuer (Holme/ Solvang, 1997, s. 104f.; Lantz, 2013, s. 46ff.). Intervjuerna har riktats mot företrädare för överförmyndare i de fem befolkningstätaste kommunerna i Skåne. Syftet är explorativt, att undersöka hur praktiken kan se ut. Det har alltså inte varit mitt mål att uppnå någon generaliserbar bedömning av praktiken.

En utgångspunkt för min analys är den konflikt som finns mellan den enskildes självbestämmande och den enskildes behov av skydd, delvis uttryckt i socialtjänstlagen (2001:453) 4 kap. $5 \S$, med att äldre ska få leva ett värdigt liv och känna välbefinnande. Att självbestämmandet kan komma i konflikt med andra intressen har tidigare framhållits av Landelius (1996, s. 121, se också prop. 1979/80:1, s. 208f.) Giertz (2008, s. 42) har dock framhållit, att självbestämmande istället för att konkretiseras i förarbetena till LSS, snarast ses som motsatsen till att utlämnas till andras godtycke.

\section{Teoretiska utgångspunkter}

Utformningen av gällande rätt och konflikten mellan de normativa grundmönster jag kallar självbestämmande och skyddsbehov, kommer att diskuteras med utgångspunkt i teorin om rätten som normativa grundmönster i ett normativt fält, som den har utformats av Anna Christensen (se till exempel Christensen, 1994). Christensen menar att det inom ett givet rättsområde finns normativa mönster $i$ konkurrens med varandra. Dessa mönster grundar sig i moraliska sedvänjor och politiska grundhållningar i samhället (se till exempel Christensen, 1996, s. 527-531) och styr ofta rättsutvecklingen (Christensen, 1994, s. 2 och 1996, s. 527-631, se vidare Ryrstedt, 2014b).

Den teori om vulnerability, på svenska utsatthetsteorin, som utvecklats av Martha Fineman, används i denna studie för att diskutera hur hjälp till exempelvis dementa äldre i förlängningen kan leda till självbestämmande. Självbestämmande är nödvändigt för att FN:s konvention om personer med funktionsnedsättning ska kunna uppfyllas. Fineman framhåller bland annat att jämlikhet inte är detsamma som formell likabehandling, eftersom likabehandling kan innebära att man inte tar hänsyn till att olika livsbetingelser har betydelse för individens behov av stöd (jämför Fineman, 2010-2011, s. 251 och 260f. se vidare Ryrstedt, 2014b).

Utsatthetsteorin innebär alltså att även om mänsklig utsatthet är allmängiltig, är den också beroende av individens specifika situation. I och för sig är alla människor utsatta, men typen av utsatthet, liksom omfattningen, varierar både mellan individerna och över tid. Motståndskraft mot utsat thet skapas när individen får möjlighet att använda sig av olika resurser eller stöd. Utsattheten minskar och självbestämmandet ökar därmed när samhället tillhandahåller sådana resurser som ger individer en möjlighet att göra val och skapa möjligheter (Fineman 20102011, s. 260, 266 och 268f. och Fineman, 2012, s. 124f., 128f. och 140, jämför också Donelly, 2014, s. 271 för olika förutsättningars betydelse). 
Rätten till självbestämmande $\mathbf{i}$ FN:s konvention om personer med funktionsnedsättning

Det finns flera konventioner som på olika sätt berör äldre dementa personers situation (se vidare Ryrstedt, 2014a). När det gäller självbestämmande är konventionen om rättigheter för personer med funktionsnedsättning viktigast. Sverige ratificerade denna konvention 2008 (SÖ 2008: 26). Redan i de standardregler som föregick konventionen, och som fortfarande gäller, återfinns regler med syfte att ge personer med funktionsnedsättning jämlika möjligheter (Standardregler, 1995, SÖ 2008:26 under Inledning f).

Standardreglerna om jämlika möjligheter och ickediskriminering fullföljs i konventionen om rättigheter för personer med funktionsnedsättning. Det uttrycks där att funktionsnedsatta har rätt att inte diskrimineras, utan istället kunna åtnjuta sina rättigheter (SÖ 2008:26, under Inledning b, se också prop. 2008/09:28, s. 15. Se vidare Nilsson, 2014).

I artikel 3 framhålls rätten till individuellt självbestämmande. Detta följs upp i artikel 5, som föreskriver en skyldighet för konventionsstaterna att vidta åtgärder som ger en skälig anpassning för att främja jämlikhet och avskaffa diskriminering. Först i artikel 12, kommer den i detta sammanhang mest relevanta artikeln. Där tydliggörs den rätt personer med funktionsnedsättning har att erkännas som personer i lagens mening. I denna artikel framhålls $i$ den svenska översättningen rätten till rättskapacitet, med ett därtill följande krav på konventionsstaterna att tillhandahålla det stöd som kan behövas. I en FN-kommentar avseende tolkningen av artikel 12, uttrycks dock att personer med funktionsnedsättning ska ha full legal capacity. Här framgår det att man avser inte bara att personen ska vara holder of rights, utan också en actor under the law. Kommentaren definierar senare legal capacity to act som att en person kan genomföra rättshandlingar (General Comment, 2014, under 4, 8, 12, 13, 14 och 15). Den svenska översättningen av konventionen har alltså valt att översätta legal capacity som enbart rättskapacitet (SÖ 2008:26). Kommentaren förklarar istället att legal capacity såväl innefattar legal standing som legal agency (General comment 2014, under 13, 14 och 15), alltså att begreppet omfattar både rättskapacitet och rättslig handlingsförmåga (se vidare Ryrstedt 14 a och b). I sammanhanget är vidare artikel 16 relevant. Denna artikel ger uttryck för bland annat att personer med funktionsnedsättning har rätt att skyddas mot utnyttjande, våld och övergrepp.

\section{Personliga beslut}

\section{Olika beslutstyper}

Denna framställning rör tre olika typer av beslutsfall. I det första fallet är det fråga om sådana personliga rättshandlingar som endast kan ingås av den enskilde själv. Ställföreträdaren kan alltså varken ingå $\mathrm{i}$ rättshandlingen, eller bistå den enskilde på ett sådant sätt att den enskildes bristande rättsliga handlingsförmåga ersätts eller kompletteras av ställföreträdarens. Om den äldre dementa personen inte 
besitter förmåga att fatta något beslut kan därför inte rättshandlingen genomföras. Ett exempel på en sådan personlig rättshandling är att ingå äktenskap. Resultatet av att två personer inte kan gifta sig, blir många gånger att de istället bor tillsammans utan att gifta sig. Frågan blir då om parternas samlevnad kan anses vara sådan att sambolagen (2003:376) blir tillämplig och vad ett sådant samboförhållande i så fall kan leda till för rättsliga konsekvenser, jämfört med ett äktenskap.

Den andra typen av beslutsfall är sådana fall där den enskilde som utgångspunkt har en egen beslutanderätt, men där denna under vissa förutsättningar kan komma att ingå i förvaltarens förordnande, som till exempel rätten att ingå arbetsavtal, 11 kap. 8 § Föräldrabalken (1949:381)(FB).

Den tredje typen av fall kan närmast beskrivas som en i stora stycken oreglerad restpost. Denna typ av handlingar saknar ofta rättsliga konsekvenser och brukar vara av en mera vardaglig karaktär. I förarbetena nämns särskilt beslut om boende och vård (prop. 1987/88:124, s. 172). Det handlar också om de relationer den dementa äldre personen vill ingå, eller vilken mat och dryck denne ska inta. Att den enskildes självbestämmande kan ha andra implikationer, som hur det på ett boende kan uppfattas att en person äter enklare mat än en annan, behandlas i detta temanummer av Harnett och Jönsson.

Denna typ av handlingar kan i vissa fall vara av stor betydelse för den enskilde. Samtidigt kan handlingar som genomförts av en dement äldre med en kognitiv funktionsnedsättning, upplevas som stri- dande mot den dementa äldres intressen av olika skäl, av till exempel närstående, ställföreträdare, eller personal. Det kan till exempel handla om en äldre dement person, som önskar bo i en objektivt sett olämplig bostad, som vederbörande inte längre klarar av att värma upp tillräckligt. Det upplevs som naturligt att till exempel personal från hemtjänsten tycker det är ovärdigt att bo så och att anhöriga, eller en ställföreträdare, reagerar med oro och anser att ett beslut utan hänsyn till den dementa äldres vilja måste fattas.

Teoretiskt ser det för denna grupp av beslut ut att föreligga en skillnad mellan när en förvaltare är förordnad för den enskildes hela livssituation och när den enskilde har hjälp av en god man, men där den gode mannen kan handla utan den enskildes samtycke. Denna teoretiska skillnad återfinns i lagtextens struktur och utformning. Någon skillnad blir det emellertid inte i praktiken.

Både god mans och förvaltares förordnande kan enligt 11 kap. 4 och $7 \S \S \mathrm{FB}$ omfatta att sörja för den enskildes person; alltså omfatta också andra handlingar än rättshandlingar. En förvaltare får enligt lagtexten ensam rådighet och företrädesrätt inom uppdraget, vilket uttrycks i 11 kap. 9 § FB. En god man får emellertid enligt 11 kap. 5 § FB som huvudregel endast rättshandlaå den enskildes räkning.

I den omfattning de åtgärder den gode mannen vidtar inte är rättshandlingar, utan till exempel ett beslut om vilken mat den enskilde ska äta, omfattas alltså inte åtgärderna av 11 kap. $5 \S$ FB. Detta kan leda till tolkningen att den gode mannen, oavsett den enskildes hälsotillstånd, aldrig 
enligt lag har att fatta denna typ av personliga beslut. Vad gäller förvaltare, har förarbetena emellertid uttryckt att en enskild under ett fullständigt förvaltarskap ändå torde ha en viss egen beslutanderätt (prop. 1987/88:124, s. 172). Resultatet blir därmed detsamma för den enskilde som har hjälp av en god man, eller en enskild som står under ett fullständigt förvaltarskap; en viss beslutanderätt ska alltid finnas kvar.

\section{Att gifta sig ${ }^{1}$}

I enlighet med vad som tidigare sagts, finns det särskilda rättshandlingar som är så personliga, att det bara är den enskilda själv som kan ingå dem. Ingåendet av äktenskap bygger på att parterna åtminstone förstår innebörden av äktenskapet; rättshandlingsförmågan måste alltså minst omfatta denna förståelse (NJA, 1994, s. 108 och 2010 s. 648. Se även prop. 1973:32, s. 97f. Se vidare Ryrstedt, 2014b). Endera parten måste alltså både ha en tydligt manifesterad vilja att gifta sig och förstå innebörden av ett äktenskap. Det handlar då såväl om den väsentliga innebörden av äktenskapet som om dess rättsliga konsekvenser (NJA, 1994, s. 108. Se även domskälen punkt 8 i NJA 2010, s. 648. Se vidare Ryrstedt, 2014b). Om någon av parterna saknar en kognitiv förmåga som når upp till den beskrivna nivån, kan vederbörande inte gifta sig. Det sagda gäller oavsett om förvaltare

1 Se för en mera utförlig beskrivning Ryrstedt, $2014 \mathrm{~b}$. eller god man är positiva till äktenskapet. Dessa har nämligen inte någon möjlighet att genom sitt samtycke läka en enskilds brist i detta avseende (prop. 1987/88:124, s. 202f, samt slutprotokollet s. 252. Se även SOU 2004:112, s. 366 och 451. Se också hovrättens skäl i RH 2008:33). Denna typ av personlig rättshandling, innebär således att rättshandlingen över huvud taget inte kan ingås om inte den enskildes kognitiva förmåga uppgår till den nivå som krävs.

\section{Att sammanbo i sambolagens mening}

När två personer befinner sig i en kärleksrelation, är resultatet ofta efter en tid att de vill flytta samman eller gifta sig. I det fall det rör sig om en situation där en av dem eller båda är dement(a), kan detta innebära att paret inte kan gifta sig. Det finns dock inte något som hindrar dem att fysiskt sammanflytta; en annan sak är hur en sådan sammanflyttning utformas om parterna bor på ett särskilt boende och vad som då krävs för att lagens krav på samboende ska vara uppfyllt. Alldeles bortsett från den antydda problematiken är det inte heller självklart om de äldre dementa personernas sammanflyttning alltid leder till att sambolagen blir tillämplig.

Ett samboförhållande konstitueras genom att parterna flyttar samman och lever stadigvarande tillsammans i ett parförhållande med gemensamt hushåll, 1 § sambolagen. Tidigare uttryckte lagtexten att paret skulle leva i ett äktenskapsliknande förhållande, då i 1 § 2 st. sambolagen i 1987 års lydelse (1987:232). Även om detta inte längre framgår av lagtexten, 
framhålls i förarbetena att någon ändring egentligen inte åsyftas (prop. 2002/03:80, s. 27f. och 43ff.).

Sättet att ingå ett samboförhållande skiljer sig alltså helt från hur två parter ingår äktenskap; där krävs det en tydlig rättshandling.

I en proposition till ändringar i giftermålsbalken har det uttryckts att det för att samlevnad av äktenskapsliknande karaktär ska kunna anses föreligga, måste parterna kunna gifta sig. Som exempel på när så inte är möjligt har angivits samlevnad mellan syskon, (prop. 1973:32, s. 168) vilket är ett äktenskapshinder.

Ett möjligt sätt att tolka förarbetsuttalandet är att det räcker att vara kapabel att faktiskt fysiskt sammanflytta och att leva stadigvarande tillsammans i ett parförhållande med gemensamt hushåll, för att ett samboförhållande enligt sambolagen ska föreligga, så länge inte något äktenskapshinder enligt lag föreligger.

Ett annat möjligt sätt att tolka förarbetena är att om någon av parterna saknar en sådan insikt om vad ett äktenskap innebär att de inte får gifta sig, kan de inte heller inleda ett samboförhållande. Det skulle alltså innebära att samma krav på kognitiv förmåga ställs på den som vill inleda ett samboförhållande som gäller för den som vill ingå äktenskap.

Min uppfattning är att eftersom samboförhållande bygger på faktiska förhållanden och inte på någon uttrycklig verbal viljeförklaring, måste viljeförklaringen anses ligga inherent i den fysiska handling som sammanflyttningen innebär. Det är ju den som konstituerar samboförhållandet. Mot den bakgrunden är det inte rimligt att kräva att vederbörande ska behöva förstå innebörden av att gifta sig för att kunna bli sambo. Min uppfattning står dessutom i samklang med det mest grundläggande syftet bakom sambolagen nämligen att skapa ett skydd för parter, särskilt den svagare parten, som lever tillsammans utan att formalisera sin relation på det sätt som sker genom ingående av ett äktenskap (se till exempel SOU 1972:41, s. 93, SOU 1981:85, s. 114).

Avståendet från krav på en viljeyttring från parterna i regleringen, har skett medvetet. Det har framhållits att krav på en sådan viljeyttring nog skulle få begränsad effekt, och att risken att en skyddsbehövande svagare part skulle lämnas utanför också kunde vara stor. Vidare framhölls att parterna ofta glider in i ett samboförhållande (SOU 1981:85, s. 136.)

Det är därför förvånande att samma förarbeten uttrycker att:

"Av det sagda bör framgå att man vid en jämförelse har att tänka sig hur ett äktenskap mellan parter i samma åldrar och i motsvarande förhållanden i övrigt normalt skulle ha gestaltat sig. Givetvis bör det fordras att båda parter samlever helt frivilligt. Däri bör även inläggas ett krav på att båda besitter erforderlig rättslig handlingsförmåga, så att inte ett obehörigt beroendeförhållande föreligger." (SOU, 1981:85, s. 140).

Här talar alltså förarbetena om den rättsliga handlingsförmågan. Den är emellertid rimligen riktad mot ingåendet av samboförhållandet. Som ovan sagts utgör 
dock själva ingåendet av samboförhållandet inte någon rättshandling i sig. Även familjelagssakkunniga själva tog upp det faktum att samboförhållandet inte är en rättshandling, när dessa framhöll att man inte ansåg sig kunna föreslå en likadelning av samtlig egendom, eftersom inte sambor ingått något avtal om detta genom att ingå äktenskap (SOU, 1981:85, s. 117).

Det är därmed svårt att avgöra vilken vikt som ska läggas vid uttalandet om att det för att samlevnad av äktenskapsliknande karaktär ska kunna anses föreligga, parterna måste kunna gifta sig (prop. 1973:32, s. 168), liksom också hänvisningen till erforderlig rättslig handlingsförmåga (SOU, 1981:85, s. 140). Härmed sammanhänger den svårighet det innebär att inte någon officiell förrättare finns med i bilden, som kan bedöma en parts möjlighet att förstå innebörden av att sammanflytta. Boende är emellertid oftast något den enskilde kan besluta om själv; det är till och med angivet i förarbetena som ett exempel på den enskildes kvarstående rätt att bestämma själv, även när denne står under ett fullständigt förvaltarskap (prop. 1987/88:124, s. 172).

Trots att jag själv har uppfattningen att övervägande skäl talar för att insikt om vad äktenskap innebär (det som idag utgör grunden för en persons rättshandlingsförmåga) inte krävs för inleda ett samboförhållande, blir alltså min slutsats att rättsläget är oklart. Denna oklarhet är olycklig eftersom en klassificering som sambo kan ha stor betydelse i olika situationer som innebär en rätt att leva tillsammans, eller att gentemot en hyresvärd få överta en lägenhet (se härför Norberg i detta temanummer).
Andra rättshandlingar, som har samband med sammanflyttningen kan dock behöva ingås, som till exempel att teckna ett hyreskontrakt.

\section{Sammanboende, egendom och arv}

Oavsett om ett äldre par väljer att leva tillsammans utan att vara gifta, eller tvingas till det beroende på att den enas eller bådas hälsosituation leder till äktenskapshinder, innebär tillämpningen av sambolagen ofta särpräglade konsekvenser just för denna kategori.

Dessa konsekvenser beror framför allt på att deras samboförhållande ofta kommer att upphöra genom att en av dem avlider - till skillnad från unga sambor där samboförhållandet ofta ersätts av ett äktenskap, eller där samborna separerar. När ett samboförhållande föreligger mellan personer som ingått detta som äldre, finns vidare normalt inte några gemensamma barn. I stället uppstår många gånger en konflikt mellan den efterlevande sambon och den avlidnes barn.

Ett äktenskap innebär som huvudregel en likadelning av makarnas giftorättsgods, när äktenskapet upplöses, 10 kap. 1 § och 11 kap. 3 § äktenskapsbalken (1987:230) (ÄktB). Vidare föreligger en viss arvsrätt; dock inte när det endast finns särkullbarn, 3 kap. $1 \S 1$ st. Ärvdabalken (1958:637) (ÄB). I ett sådant fall föreligger dock en skyddsregel till förmån för den efterlevande maken. Denna kallas basbeloppsregeln, 3 kap. 1 § 2 st. ÄB. Denna innebär en rätt för den efterlevande maken att erhålla egendom som tillsammans med 
det som maken erhöll vid bodelningen, liksom med den enskilda egendom maken har, motsvarar fyra gånger det prisbasbelopp enligt 2 kap. 6 och $7 \S \S$ Socialförsäkringsbalken (2010:110), som gäller vid tiden för dödsfallet. Denna rätt för den efterlevande maken gäller dock endast så länge kvarlåtenskapen efter den avlidne maken räcker.

För sambor innebär inte en upplösning av förhållandet en lika långtgående fördelning. Där delas endast den så kallade "samboegendomen". Även här är dock likadelning huvudregel, $14 \S$ sambolagen. Det föreligger inte heller någon arvsrätt för en efterlevande sambo. Den basbeloppsregel som också här utgör en skyddsregel, är i stället en bodelningsregel som kan tillämpas vid en sambos död. Denna är dock, som benämningen antyder, av mindre omfattning än motsvarande arvsrättsliga bestämmelse i ärvdabalken. Regeln innebär en rätt för en efterlevande sambo att erhålla så mycket av den behållna samboegendomen, efter avdrag för skulder, att det motsvarar två gånger det vid tiden för dödsfallet gällande prisbasbeloppet enligt 2 kap. 6 och $7 \S \S$ Socialförsäkringsbalken. Det är också här en förutsättning att egendomen räcker, $18 \S$ sambolagen.

Resultatet av det ovan sagda innebär således att samboförhållandet innebär ett lägre skydd för den svagare parten än ett äktenskap. Ett samboförhållande kan innebära samma nivå av ekonomisk sammanblandning som äktenskapet oavsett om samborna är äldre eller yngre. Satt i kontext av att ett sammanboende som ingåtts av äldre, ofta upphör genom den ena sambons död, kan därmed konsekvenserna för den efterlevande sambon bli mera allvarliga än vad ett upphörande av ett samboförhållande annars innebär.

\section{Arbete}

Enligt 11 kap. $8 \S, 1$ st., 1 och 2 punkterna FB kvarstår som huvudregel den enskildes rätt att själv sluta avtal om tjänst eller annat arbete också där förvaltare är förordnad. Det som vederbörande då, efter att förvaltare har förordnats, förvärvar genom eget arbete får, likaledes som huvudregel, den enskilde själv förfoga över. Det sagda gäller också avkastningen av egendomen, liksom substitut för den. I paragrafens andra stycke sägs att rätten, där särskilda skäl föreligger, får föreskriva att förvaltaruppdraget ska omfatta även rättigheten att sluta sådana avtal, arbetsinkomsten, avkastning och substitut. Inte ens ett generellt förordnande innefattar alltså dessa områden. Istället framhålls i förarbetena att det krävs att det anges särskilt i förvaltarförordnandet att dessa områden ska omfattas (prop. 1987/88:124, s. 170).

De särskilda skäl som regleringen stipulerar för att förordnandet ska omfatta även detta, ställer tämliga höga krav på den skadliga inverkan det kan ha på den enskilde att själv få sluta avtal om arbete eller annan tjänst, eller själv få förfoga över den egendom detta arbete ger upphov till. Särskilda skäl att låta förvaltaruppdraget omfatta även ovanstående områden kan till exempel vara att den enskildes val av arbete är uppenbart olämpligt för honom (prop. 1987/88:124, s. 170f.). Det kan också föreligga en påtaglig risk att den enskilde 
kan komma att använda sin arbetsinkomst på ett sätt som kan skada denne (prop. 1987/88:124, s. 146 och 170f.). Den enskildes eventuella överkonsumtion, eller brist på sparsamhet, faller dock inte inom den gräns som skadliga ändamål utgör när det gäller förfogandet över arbetsinkomsten. Istället kan exempel på detta vara ett uttalat alkoholmissbruk eller där den enskilde förstör sin egendom. (prop. 1987/88:124, s. 170f.).

Någon motsvarande reglering finns inte för gode män. Eftersom regleringen om gode män utgår från att den enskildes rättsliga handlingsförmåga inte påverkas av att den enskilde har en god man och att den gode mannen som huvudregel måste ha den enskildes samtycke för att rättshandla, uppstår i det "vanliga" fallet inte något problem. En god man kan emellertid många gånger fatta beslut utan att tillfråga sin huvudman. I sådana situationer finns inte någon särreglering för exempelvis rätten att ingå avtal om arbete. Trots detta är det även i denna situation rimligt att förutsätta att reglerna inte kan vara mer inskränkande för den som står under god man, än den som står under förvaltare. Samtidigt bör det framhållas att när den dementa äldre personens samtycke inte behöver inhämtas, är personen troligen inte heller i stånd att ingå ett avtal om arbete. Därmed kan nog förutsättas att Odlöws uppfattning om att personer med förvaltare sällan har någon arbetsinkomst (Odlöw, 2005, s. 247), också gäller personer med gode män som kan handla utan samtycke.

Med tanke på att innevarande studie adresserar äldre dementa personer, bör kanske särskilt poängteras att pensionsmedel inte här likställs med arbetsinkomst, även om pensionen alltså grundar sig på förvärvsarbete (prop. 1987/88:124,s. 171).

\section{Egen förfoganderätt}

Den enskilde har, enligt 11 kap. 8 § 1 st. 3 punkten $\mathrm{FB}$, som huvudregel bibehållen rätt att förfoga över egendom som denne, efter det att förvaltare anordnats, har fått genom gåva eller testamente, eller som förmånstagare vid försäkring eller pensionssparande enligt lagen (1993:391) om individuellt pensionssparande. På samma sätt som för arbetsinkomsterna kan denna bibehållna rättshandlingsförmåga dock upphöra om särskilda skäl föreligger. I enlighet med 11 kap. $8 \S 2$ st. FB kan rätten föreskriva att förvaltaruppdraget ska omfatta även dessa rättshandlingar, exempelvis om det finns en påtaglig risk att den enskilde kan komma att använda egendomen på ett sätt som kan skada denne (prop. 1987/88:124, s. 146 och 170f.). Denna förfoganderätt för den enskilde och möjligheten att dra in egendomen i förvaltaruppdraget berörs inte vidare i förarbeten, praxis eller doktrin.

Det finns inte någon motsvarande reglering för gode män. Eftersom institutet god man utgår från att den enskildes rättsliga handlingsförmåga inte påverkas av att denne har en god man, behövs inte det heller. Om emellertid den gode mannen kan fatta beslut utan den enskildes samtycke torde också egendom med föreskrift om särskild förfoganderätt, omfattas. Precis som för rätten att ta arbete, 
är det även i denna situation rimligt att förutsätta att reglerna inte kan vara mer inskränkande för den som står under god man, än den som står under förvaltare.

\section{Andra väsentliga personliga beslut}

Utöver de områden som ovan diskuterats, framhålls i förarbetena att en enskild alltid bör ha kvar en viss självständighet, även om en förvaltare har förordnats (prop. 1987/88:124, s. 172). Detta bör, enligt min uppfattning också gälla när en god man har förordnats och denne kan rättshandla utan den enskildes samtycke. I förarbetena ges sedan tre exempel. Det ena är inom den sociala vårdlagstiftningen. Där talar förarbetena om att den enskilde bör: "tillerkännas en viss självständighet", men man utgår samtidigt från att även ställföreträdaren kan rättshandla (jämför prop. 1987/88:124, s. 172). Det handlar alltså inte här om att den enskilde har någon alldeles egen rätt att rättshandla, även om denne alltså skulle kunna göra så.

I propositionen fortsätter man att diskutera boende och erbjuden vård. Här framstår uttryckssätt och ordval mera som om vad som avses är den enskildes självbestämmande med utgångspunkten att ställföreträdaren normalt inte ska fatta beslut på området. Samtidigt medger ordval som "i allmänhet" och "i normala fall" att det framstår som förarbetenas uppfattning att det finns en möjlighet för förvaltaren att fatta de beslut som det kan finnas behov av. När det gäller till exempel operationer måste den enskilde normalt samtycka, men det hindrar inte att ställfö- reträdarens uppfattning inhämtas (jämför prop. 1987/88:124, s. 172).

Den personliga arten av vårdrelaterade beslut har framhållits som skäl för att inte ens en förvaltare har en självständig beslutanderätt, i alla fall inte om patienten nekar att ta mot den erbjudna vården (SOU, 2004:112, s. 577, jämför också Rynning, 1994, s. 301ff.). Ställföreträdarens samtycke kan alltså i många fall vara av betydelse där patientens uppfattning är okänd, eller denne inte kan ge uttryck för sin mening, men ställföreträdarens mening får inte strida mot den mening man kan anta vara patientens (prop. 2002/03:50, s. 140, se även SOU 2004:112, s. 577). Motsvarande gäller enligt Rynning också lagen (1993:387) om stöd och service till vissa funktionshindrade (LSS), trots att den i $\sin 8 \S$ tydligt uttalar att till exempel en ställföreträdare kan begära åtgärder, där den enskilde uppenbart saknar förmåga att på egen hand ta ställning i frågan. Med utgångspunkt i dessa uttalanden om vård respektive insatser enligt LSS, kan nog tolkningsvis antas, att motsvarande gäller den dementa äldre personens boende.

I socialtjänstlagen (2001:453) 5 kap. 4 § 1 st, regleras vikten av att äldre personer får leva ett värdigt liv och känna välbefinnande (värdegrund). Där framhålls också vikten av människors självständighet under trygga förhållanden. I Socialstyrelsens allmänna råd poängteras bland annat att den äldres personlighet och identitet ska styra hur den äldre lever, att den äldre själv ska få bestämma om den kroppsliga omsorgen, få stöd att upprätthålla sitt oberoende, och att hjälp och stöd ska anpassas 
till de behov, förutsättningar och önskemål som föreligger (SOSFS 2012:3, s. 3f.).

\section{Exempel från Socialstyrelsens etiska råd}

Socialstyrelsens etiska råd har givit uttryck för sin uppfattning rörande bland annat kvarstående beslutanderätt för dementa äldre personer. Rådet poängterar att uttalandena är att se som "ett sätt att tänka" (se Etik i socialtjänsten $u$ å). Det etiska rådet fokuserar i dessa svar på rätten till självbestämmande. Ett exempel på detta är situationen där två personer inleder en kärleksrelation, trots att en av dem är gift. Det etiska rådet menar i denna situation att någon hänsyn inte ska tas till annat än den dementa personens önskemål och rätt till privatliv (Ska personal i demensboende motverka otrohet mellan boende? $\mathrm{u}$ å). I ett annat fall poängteras dock att båda parterna har full rättslig handlingsförmåga, utan att det egentligen anges vilken betydelse detta skulle ha (Berätta för anhöriga om kärleksrelation u å).

Samtidigt finns emellertid också exempel på situationer där den enskildas självbestämmande får inta en mera underordnad ställning, eftersom den står i konflikt med andra enskildas intressen och dessa intressen ses som legitima. Ett sådant exempel angår en man som inte vill duscha. Han har över huvud taget inte tagit av sig kläderna på 13 veckor. Det framgår här att den enskilde, som bor på ett demensboende, har en god man. Det etiska rådet ställer sig dock mycket tveksamt till om denne har så långt gående befogenheter, att han för den enskildas räkning kan medge tvångsvisa hygienåtgärder. I detta fall intar dock det etiska rådet en tämligen pragmatisk ställning. Rådet väger den enskildas rätt till självbestämmande mot risken för hälsoproblem, påverkan på andra boende, samt på personalens arbetsmiljö. Även om rådet här försöker ange olika möjligheter att "locka" den enskilde att förbättra sin hygien, redovisar man också vissa ledamöters inställning att tvång genom lugnande mediciner kanske är det bästa, trots att det framhålls vara otillåtet (Hur får man en duschvägrare att tvätta sig? u å).

Ett annat fall gäller stor alkoholkonsumtion som ledde till att mannen ifråga levde i misär på sitt vårdboende. Mannen hade flera gånger avböjt hjälp med sitt beroende. Etiska rådet hänvisade här till socialtjänstlagen och hälso- och sjukvårdslagen och uttalade att mannens självbestämmande innebar att han hade rätt att tacka nej till insatser. Vidare framhölls vikten av frivilliga insatser. Till slut anfördes dock: "Skulle [...] ändå avvisa alla former av konstruktiv dialog med personalen bör de överväga att på olika sätt reducera hans möjlighet att få tag på alkohol." (Hur ge god vård till man med destruktivt alkoholmissbruk? u å).

I ett annat fall med en diabetessjuk utvecklingsstörd man, som åt på ett ohälsosamt sätt, uttalade etiska rådet: "Förvaltaren ska givetvis ta hänsyn till önskemål från den enskilde, men ska också beakta vad som kan vara nyttigt eller skadligt ur hälsosynpunkt för [...]."(Hur hanterar man en man med stor aptit och diabetes? $\mathrm{u}$ å). I ett fall med en demenssjuk kvinna som 
trots sin allt svårare demens ville bo kvar i sitt hem, uttalade etiska rådet att kvinnan själv hade rätt att bestämma hur hon skulle bo. Demensen innebar inte att hon inte kunde uttala en vilja (Kvarboende i det egna hemmet, u å).

\section{Personliga beslut och synen hos informanterna}

Jag har genomfört ett antal intervjuer med företrädare för olika överförmyndare. Dessa har genomgående haft uppfattningen att sådana personliga beslut som boende, relationer, mat och dryck alltid måste fattas av den enskilde; och att de alltså inte fär fattas av en ställföreträdare. Att ställföreträdare har en uppfattning om det saken rör är förstås en helt annan sak.

När den äldre dementa personen blir så dålig, att denne inte längre förstår vad det innebär att bo kvar i det ursprungliga hemmet, alternativt att bo till exempel på ett demensboende, anses beslutet av fyra av fem informanter kunna fattas över dennes huvud. Frågan om vad den enskilde förstår, avgörs via ett läkarintyg. Detta anser dessa informanter innebära att en enskild som förstår vad beslutet innebär, får bestämma var denne ska bo, även om det skulle innebära att den enskilde lever i misär. En informant framhåller dock att missförhållandena nog så småningom leder till sjukdom, vilket i sin tur leder till att vård kan komma att ges. En annan informant menar att den enskildes uppfattning alltid ska efterfrågas och i regel gälla oavsett om denne förstår konsekvenserna av sitt svar eller ej; det ska alltså inte vara möjligt att tvinga den enskilde, så länge denne kan uttrycka vad denne vill.

I vissa situationer kan ställföreträdaren använda sig av sitt förordnande, för att uppnå den önskade situationen. Ett exempel som en informant anger, är att en enskilds beslut om boende kan stå i direkt motsats till vad ställföreträdaren anser vara det bästa för den enskilde. Ställföreträdaren kan då i vissa fall sälja eller säga upp den enskildes boende, så att denne inte har något annat val än att acceptera boendet ställföreträdaren föreslår. Detta sker i så fall utan lagstöd och utan att det är sanktionerat av överförmyndaren och företrädesvis när den enskilde vistas på sjukhus. Övriga informanter anser inte detta vara en korrekt väg att gå.

Vidare är uppfattningen att en enskild alltid själv bestämmer om sina relationer. Denna bestämmanderätt kan dock inskränkas av att det finns vissa regler om störningar osv. som omfattar den enskildes boende (se JO dnr 3711-2004, för skillnaden mellan sjukhem och boende i egna lägenheter). Två informanter anger att ställföreträdaren i vissa grava fall kan undersöka möjligheten att ansöka om kontaktförbud.

Vad gäller utgifter för mat och dryck, liksom synpunkter på vad för mat och dryck som den äldre dementa personen ska köpa, anger samtliga informanter att det inte i sig finns några restriktioner, så länge den äldres ekonomi tillåter utgifterna. Samtidigt framhåller fyra av fem informanter att förvaltaren teoretiskt sett kan styra över vilken mat och dryck som köps, genom att denne disponerar över hur mycket pengar den enskilde ska

Eva Ryrstedt: Får jag inte bestämma något själv? 
ha tillgång till. En informant menar att det beror på en överenskommelse mellan ställföreträdaren och den enskilde. En annan informant angav att den enskilde måste förstå sin situation och att det är individuellt hur förvaltaren gör.

Om ställföreträdaren exempelvis vill hålla nere en alkoholkonsumtion, kan det alltså göras genom att den enskilde inte får tillgång till så mycket pengar. En informant framhåller, att så kan behöva ske vad gäller alkoholkonsumtion som negativt samverkar med mediciner. Åtgärden får då vidtas i samråd mellan behandlande läkare och förvaltaren. En annan informant framhåller att även om det inte föreligger några egentliga restriktioner för hur mycket en enskild får spendera på mat och dryck, får den mera ekonomiska synen fortfarande genomslag. Detta har betydelse eftersom det till syvende och sist är förvaltaren som fattar besluten.

Samtliga informanter framhåller också att det är den enskilde själv som fattar beslut om den egna vården; även om de också framhåller den behandlande läkarens ansvar.

\section{Om huvudmannen inte är nöjd}

Den enskildes hälsotillstånd - det som utgör själva grunden för att vederbörande har en ställföreträdare - är paradoxalt nog avgörande för en dement äldre persons möjlighet att reagera mot ställföreträdaren. Det är svårt att klaga för den vars kognitiva förmåga sviktar. Detta leder till att möjligheten att uppnå en förändring $i$ sin tur blir beroende av att vederbörande får hjälp eller stöd i den situation denne befinner sig i.

När samarbetet mellan den enskilde och dennes ställföreträdare inte fungerar, finns möjligheten att byta god man eller förvaltare. En ansökan om entledigande, kan göras av någon i den krets, som också kan ansöka om att god man eller förvaltare ska anordnas eller förordnas. Ansökan kan också göras av den gode mannen eller förvaltaren. Rätten eller överförmyndaren får också självmant ta upp frågan om entledigande där de är behöriga att avgöra frågan, 11 kap. 21 § FB. Härtill kommer att överförmyndaren i allmänhet kan initiera en rättens åtgärd genom ansökan (Walin/ Vängby, 2001, under 11 kap. 20 och 21 §§ $\mathrm{FB})$.

Det sagda innebär således att bland annat den enskilde själv kan ansöka om att den gode mannen eller förvaltaren ska entledigas

Beslutet att entlediga god man eller förvaltare fattas av överförmyndaren. Beslutet bygger på att ställföreträdare gjort sig skyldig till missbruk eller försummelse när denne har utövat uppdraget, att denne kommer på ekonomiskt obestånd, eller att denne av någon annan orsak inte längre är lämplig att inneha uppdraget. (11 kap. $20 \S 1$ st. FB.)

Samtliga informanter i de genomförda intervjuerna menar att huvudmännen $\mathrm{i}$ första hand bör klaga till överförmyndaren om de inte är nöjda med ställföreträdarens sätt att sköta sin uppgift. De kan då få byta; denna möjlighet behandlades dock något olika. Två av informanterna anser att så ska ske om det är möjligt, medan två andra informanter menar att det före- 
kommer att byten sker och en att det inte är enkelt att få byta. Beslutet fattas efter en bedömning av graden av samarbetsproblem och vad samarbetsproblemen består i. Två informanter framhåller dock att det kan vara svårt för en "halvdålig" enskild att klaga. En av dessa framhåller också att den enskildes isolering kan vara stor och en annan att den faktiska möjligheten att byta ställföreträdare kan bero på om den enskilde kan uttrycka sig. En informant framhåller att det inte ofta var missbruk eller försummelse som låg bakom klagomålen på ställföreträdaren.

Möjligheten att byta god man eller förvaltare, synes således bero både på vilken hjälp en enskild kan få av de som finns runt denna, liksom också överförmyndarens inställning och vilja i sammanhanget.

\section{Självbestämmande eller skydd - en analys}

I denna artikel behandlas i vilken omfattning och på vilka områden som en enskild med ställföreträdare, har en kvarstående beslutanderätt. Dessa områden kan delas in i tre grupper, som var och en har sina egna förtecken. De regler som ligger bakom dessa tre grupper är visserligen i sig otydliga, men framstår utifrån Christensens $(1994,1996)$ begrepp i huvudsak bygga på en konflikt mellan de normativa grundmönstren självbestämmande och skyddsbehov. Vid en mera ingående undersökning är det emellertid inte säkert att det som i förstone framträder som byggt på till exempel det normativa grundmönstret självbestämmande, är så klart.
Den första gruppen av beslut är ett tydligt exempel på detta. Inom denna grupp måste individen själv ingå rättshandlingen för att någon rättshandling över huvud taget ska kunna komma till stånd. Här kan det se ut som om rättshandlingsförmågan är både det betydelsefulla och det som bevaras för individens räkning. Det skulle alltså utgöra ett utflöde av det normativa grundmönstret självbestämmande. I verkligheten är det i stället fråga om att vi bedömer vilken rättslig handlingsförmåga den dementa äldre har och ställer vissa krav på denna för att rättshandlingen ska kunna ingås. Det handlar alltså varken om att bevara rättshandlingsförmågan, eller att hjälpa den dementa äldre personen, så att denne kan fatta ett informerat beslut (för denna term se vidare Rynning, 1994, s. 23ff.). Istället handlar det endast om vad som kvalificerar individen att fatta ett beslut, det vill säga i praktiken något som istället beror på det normativa grundmönstret skyddsbehov.

Det är här viktigt att adressera de konsekvenser som följer av att rättshandlingsförmågan brister i detta avseende och det äldre dementa paret, som i mitt tidigare exempel, inte kan gifta sig. Resultatet av oförmåga att ingå en rättshandling som äktenskap, leder ofta inte till annat än att den fysiska sammanlevnaden blir densamma, men följt av mindre omfattande rättsföljder vid förhållandets upphörande.

I den andra typen av beslut, handlar det till exempel om huvudregeln om att ha rätt att ingå ett arbetsavtal. Här rör det sig om rättshandlingar som den enskilde normalt har möjlighet att ingå också i situationer där den rättsliga handlingsförmågan annars 
är fråntagen denne. Denna huvudregel kan dock inskränkas genom att förordnandet kan komma att omfatta även dessa typer av beslut. Självbestämmandet har därmed en mera pragmatisk prägel och de två normativa grundmönstren är i balans.

Den tredje typen av beslut är beslut av mera vardaglig eller personlig art, som till exempel beslut om den enskildes boende, vård, dennes relationer, eller vilken mat och dryck denne ska inta. Detta har den enskilda, enligt vad som sagts i detta arbete, att besluta om själv. Den rättsliga grunden står främst att finna i förarbetena. Även om de av mig genomförda intervjuerna inte är en rättskälla i vanlig mening, är det intressant att notera att dessa har bekräftat uppfattningen. Min uppfattning i fråga om vardagliga beslut harmonierar också med de exempel som angivits från Socialstyrelsens etiska råd, även om de också tycks inta en tämligen pragmatisk hållning. Dessa uttalanden har ett lågt värde som rättskälla.

Individens kvarstående beslutanderätt framstår dock inte av praktiken som absolut. Istället tycks den centrala frågan vara att individen måste förstå handlingen och dess konsekvenser, för att det ska finnas någon beslutanderätt kvar. I intervjuerna har detta varit tydligt framför allt vad gäller boendet. Om nu inte den enskilde förstår handlingen och konsekvenserna, men väl har en emotionell vilja inriktad på till exempel sitt eget boende, är det då mindre värt och behöver inte beaktas? Det verkar faktiskt vara konsekvensen av nuvarande rättstillämpning. Resultatet av min rättsdogmatiska undersökning och min intervjuundersökning sammanfaller i det att emotionell vilja har en klart underordnad roll i förhållande till kognitivt medveten vilja. Enligt min bedömning ökar det sannolikheten för att det som sägs i mina intervjuer, också gäller i de kommuner som inte undersökts.

Denna inställning till kvarstående beslutanderätt, bör sättas i en teoretisk och metodologisk kontext. Finemans teori om vulnerability innebär att alla människor är utsatta $\mathrm{i}$ viss mån någon gång under livet, men att även dessa personer kan bli självbestämmande om de får hjälp, (Fineman, 2010-2011, s. 260. Se också Fineman, 2012, s. 124f. ) i stället för att man låter skyddsbehovet ta över. Detta kan innebära att det går att undvika att hjälpbehovet leder till en reglering där någon helt enkelt övertar beslutanderätten.

Finemans tes om vikten av självbestämmande, är konsistent med de rättigheter som framkommer i FN:s konvention om rättigheter för personer med funktionsnedsättningar, så som den bör tolkas, där självbestämmandet innebär rättslig handlingskapacitet (se vidare Ryrstedt, 2014a och b). Konventionen innebär alltså att det ställs ett starkt krav på individens rätt att rättshandla. För att ett sådant självbestämmande ska kunna uppnås, med bibehållande av till exempel den rätt som samtidigt finns för personer med funktionsnedsättningar att skyddas mot utnyttjande enligt art. 16, blir det en nödvändig konsekvens att självbestämmandet uppnås genom hjälp till den enskilde.

I det avseende som gäller den nämnda konventionen, är dementa äldre personers kvarstående beslutanderätt av särskilt intresse ur perspektivet att det på 
detta personliga område blir tydligt vilka problemen med självbestämmande blir. En avvägning mellan dementa äldre personers olika intressen måste göras i en hållbar rättstillämpning. Min uppfattning är att en rättslig praktik, som lägger avgörande vikt vid att den demente kognitivt ska förstå innebörden av olika handlingar och som därmed tar för lite hänsyn till uttryck för en emotionell vilja, står i strid med konventionen.

Det sagda kan sättas i ett vidare perspektiv med hjälp av teorin om normativa grundmönster (Christensen, 1994, 1996). De normativa grundmönstren självbestämmande kontra skyddsbehov förklarar dagens reglering på de områden jag här adresserar. Samtidigt kan mönstren utgöra en bas för en diskussion om en trolig framtida utveckling. De nämnda mönstren sätter särskilt tydligt fokus på den avvägning mellan de äldre dementas olika intressen som måste göras i en hållbar reglering på detta personliga område. Ett tydligt exempel på när skyddsbehovet har fått ta överhanden, är om det är svårt för en enskild att framföra klagomål på den som är satt att hjälpa honom, och att så kan vara fallet idag har framgått av intervjuerna. I en utveckling av regleringen torde därför ligga behov av en möjlighet för den dementa äldre personen att få hjälp för att klaga på den som är satt att bistå vederbörande.

Med den utveckling som pågår, där konventionen om personer med funktionsnedsättningar är ledande, är det troligt att samhällsutvecklingen kommer att innebära allt större fokus på självbestämmande och då i första hand på de områ- den som är fokus för denna studie. Det är därför rimligt att förutsätta att skyddsbehovet även fortsättningsvis kommer att inta en viktig plats, inte minst för att hindra utnyttjande.

Även för personer som inte har någon som helst möjlighet att förstå framför allt konsekvenserna av vissa beslut, alldeles oavsett hur mycket hjälp de får, måste nog i framtiden frågan om emotionellt självbestämmande lyftas fram. Så är fallet i alla fall om vi ska följa konventionen om personer med funktionsnedsättning. Samtidigt leder en acceptans av också en emotionellt baserad vilja, kanske också till att många äldre dementa personer kommer att leva på ett sätt som inte står i samklang med det som andra tycker är bäst för dem och alltså därmed inte alltid vare sig känna välbefinnande eller ha ett värdigt liv.

Självbestämmande relativt skyddsbehov är därför kanske den fråga som till syvende och sist avgör hur vi ska se problemet med äldre dementa personer. Även om detta är mönster som i förstone ser ut att vara i konflikt med varandra, går det inte att bortse från det nära förhållande dem emellan som samtidigt föreligger. Denna närhet beror på att självbestämmande inte rimligen kan uppnås utan bistånd. Den viktiga frågan blir istället hur detta bistånd ska ges för att främja självbestämmande och fokus på den enskildes vilja och önskningar.

Ett regelsystem behöver därför utvecklas, där fokus ligger på självbestämmande, också när den enskilde saknar insikt i konsekvenserna av de beslut som fattas, men där det finns ett skydd, såväl emot externa faror som interna, inbyggt i systemet. 
Ett sådant system kan bygga på respekt för individens olika utvecklingsfaser och de förändringar som äger rum under vederbörandes liv. Här kan det då bli fråga om den dementa äldre personens möjlighet att när de kognitiva förmågorna kvarstår, fatta beslut som rör individens senare liv. Samtidigt bör självklart den personlighet som så småningom framträder respekteras, så att självbestämmandet kan omfatta nya beslut. Ett sådant självbestämmande bör då ingå i ett system, där individen ges tolkningshjälp, för att det ska gå att fastställa vederbörandes önskemål och ett fristående bistånd utformas med fokus på individen, ungefär på det sätt som görs till exempel i Storbritannien (se härför Herring, 2014, s. 305).

Det utökade skyddsperspektiv som nog måste föreligga i en välfärdsstat med omsorg om individerna, kan då ta sikte på beslut i den situationen att den dementa äldre personen annars skulle på ett allvarligt sätt kunna fara illa. Denna typ av reglering måste kanske, för att säkerställa att den inte används annat än när samhället finner det helt nödvändigt, falla in under en reglering om tvångsåtgärder. De ska präglas av tydlighet, objektivitet och omsorg om individen. 


\section{Referenser}

Christensen, Anna (1994). Hemrätt i hyreshuset. Stockholm: Juristförlaget.

Christensen, Anna (1996). Skydd för etablerad position - ett normativt grundmönster, Tidskrift for Rettsvitenskap: 519-574.

Donelly, Mary (2014). A Legal Overview. I Charles Foster, Jonathan Herring, Israel Doron (red.) The Law and Ethics of Dementia, 271281. Oxford:Hart publishing.

Fineman, Martha Albertson (2010-2011). The Vulnerable Subject and The Responsive State, Emory Law Journal, 60 (2): 251-276.

Fineman, Martha Albertson (2012). Elderly' as Vulnerable: Rethinking the Nature of Individual and Societal Responsibility, Emory Legal Studies Research Paper 12-224: 101-142.

FN:s standardregler 1995. http://www.independentliving.org/standardrules/STILStandardRegler2.html, 2014-06-24.

FN:s konvention om rättigheter för personer med funktionsnedsättning. SÖ 2008:26.

General Comment No 1 (2014). on the Convention on the Rights of Persons with Disabilities, Article 12: Equal recognition before the law. By the Committee on the Rights of Persons with Disabilities, http://tbinternet.ohchr. org/_layouts/treatybodyexternal/Download. aspx? symbolno $=\mathrm{CRPD} / \mathrm{C} / \mathrm{GC} / 1 \&$ Lang=en, 2014-10-12

Giertz, Lottie (2008). Ideal och vardag - inflytande och självbestämnande med personlig assistens. 2008:4. Växjö: Institutionen för vårdvetenskap och socialt arbete.

Herring, Jonathan (2014). Best Interests and Dementia. I Charles Foster, Jonathan Herring, Israel Doron (red.) The Law and Ethics of Dementia, 301-310. Oxford:Hart publishing.

Holme, Idar, Magne \& Solvang, Bernt Krohn (1997). Forskningsmetodik: Om kvalitativa och kvantitativa metoder. 2:a uppl. Lund:Studentlitteratur. JO dnr 3711-2004.

Jönsson, Håkan \& Harnett, Tove (2014). Sill och potatis till den ena och entrecote till den andra? Likvärdighet och individanpassningar på särskilda boenden för äldre. Socialvetenskaplig tidskrift.

Landelius, Ann-Charlotte (1996). Självbestämmande, valfrihet och samtycke inom socialtjänsten, Stockholm: Nerenius \& Santérus.

Lantz, Annika (2013). Intervjumetodik. 3 uppl. Lund: Studentlitteratur.

Lehrberg, Bert (2010). Praktisk juridisk metod. 6:e uppl. Uppsala: Institutet för bank- och affärsjuridik.

Mattsson, Titti, Broström, Linus \& Johansson, Mats (2014). Vilka personer saknar förutsättningar att ge informerat samtycke till att delta i forskning; en rättslig och etisk diskussion rörande etikprövningslagens regler och tillämpning. Förvaltningsrättslig Tidskrift. (1): 171-183.

Nilsson, Anna (2014). Objective and reasonable? Scrutinizing compulsory mental health interventions from a non-discrimination perspective. Human Rights Law Review 14(3): 459485.

NJA 1994, s. 108.

NJA 2010, s. 648.

Norberg, Per (2014). Hem eller vårdplats - hur tillgodoses de äldres och funktionshindrades behov i hyreslagstiftningen? Socialvetenskapligtidskrift.

Odlöw, Torbjörn (2005). Ställföreträdare för vuxna: Kamrer eller handledare? Diss., Göteborgs universitet.

Proposition 1973:32. med förslag till lag om ändring i giftermailsbalken, $m$.m. Stockholm: Justitedepartementet.

Proposition 1987/88:124. om god man och förval tare. Stockholm: Justitedepartementet.

Proposition 2002/03:50. Etikpröuning av forskning. Stockholm: Justitedepartementet.

Proposition 2002/03:80. Ny sambolag. Stockholm: Justitedepartementet.

Proposition 2008/09:28. Mänskliga rättigheter för personer med funktionsnedsättning. Stockholm:

Eva Ryrstedt: Får jag inte bestämma något själv? 
Socialdepartementet. RH 2008:33.

Rynning, Elisabeth (1994). Samtycke till medicinsk vård och behandling: en rättsvetenskaplig studie. Diss: Uppsala universitet. Ryrstedt, Eva (2014a). Ställföreträdare och självbestämmande Manus. Ryrstedt, Eva (2014b). Dementa äldre; vem bestämmer?, Manus.

SOSFS 2012:3 Värdegrunden i socialtjänstens omsorg om äldre. Stockholm: Socialstyrelsen.

Socialstyrelsens etiska råd. $\mathrm{u}$ å. Socialstyrelsen. http://www.socialstyrelsen.se/etikisocialtjansten, 2014-05-25.

Socialstyrelsens etiska råd. Berätta för anhöriga om kärleksrelation u å. Socialstyrelsen. http:// www.socialstyrelsen.se/etikisocialtjansten/ berattaforanhorigaomkarleksrel, 2014-05-25.

Socialstyrelsens etiska råd. Ska personal i demensboende motverka otrohet? u å. Social styrelsen. http://www.socialstyrelsen.se/etikisocialtjansten/skapersonalregleraotrohetmella, 2014-05-25.

Socialstyrelsens etiska råd. Hur får man en duschvägrare att tvätta sig? u å. Socialstyrelsen. http://www.socialstyrelsen.se/etikisocialtjansten/hurfarmanenduschvagrareatttvat 201405-25.
Socialstyrelsens etiska råd. Hur ge god vård till man med destruktivt alkoholmissbruk? u å. Socialstyrelsen. http://www.socialstyrelsen.se/ etikisocialtjansten/hurgegodvardtillmanmeddestrukt 2014-06-13.

Socialstyrelsens etiska råd. Hur hanterar man en aggressiv man med stor aptit och diabetes? u å. Socialstyrelsen. http://www.socialstyrelsen.se/ etikisocialtjansten/hurhanteraaggressivmanmedstora2014-06-13.

Socialstyrelsens etiska råd. Kvarboende i det egna hemmet $u$ å. Socialstyrelsen. http:// www.aldreicentrum.se/till-tidskriften/2007-20005/Nr-32006--Etik-i-praktik1/ Exempel-ur-Socialstyrelsens-etiska-rad/, 2014-06-13

SOU 1972:41. Familjelagssakkunniga. Familj och äktenskap.Stockholm: Allmänna förlaget.

SOU 1981:85. Familjelagssakkunniga. Äktenskapsbalk. Stockholm: Allmänna förlaget.

SOU 2004:112. Frågor om förmyndare och ställföreträdare för vuxna. Stockholm: Fritze.

Walin, Gösta/Vängby, Staffan 2014. Föräldrabalken. En kommentar. Supplement 14. Stockholm: Norstedts förlag. 


\section{Summary}

\section{Don't I get to decide anything for myself? A study of remaining rights to make decisions}

This paper deals with the remaining right to make certain decisions an elderly person with dementia may have, despite the presence of an administrator or a "good man" (a custodian or administrator with limited power). The study encompasses both legal actions and other more ordinary decisions. These decisions are especially interesting from the perspective that they entail decisions in the most basic personal area of a person's life.

The study is conducted both through a legal dogmatic method and through a qualitative method consisting of semi-structured interviews aimed at representatives of chief guardians. The main focus of the concluding analysis is the importance of whether the elderly person with dementia truly understands a particular issue and its consequences or whether the mere emotional will should be enough to found an autonomy within this area. Finally I argue that we need a balance between autonomy taken in a broad sense of the word and protection of the individual, mainly in the terms of support. 